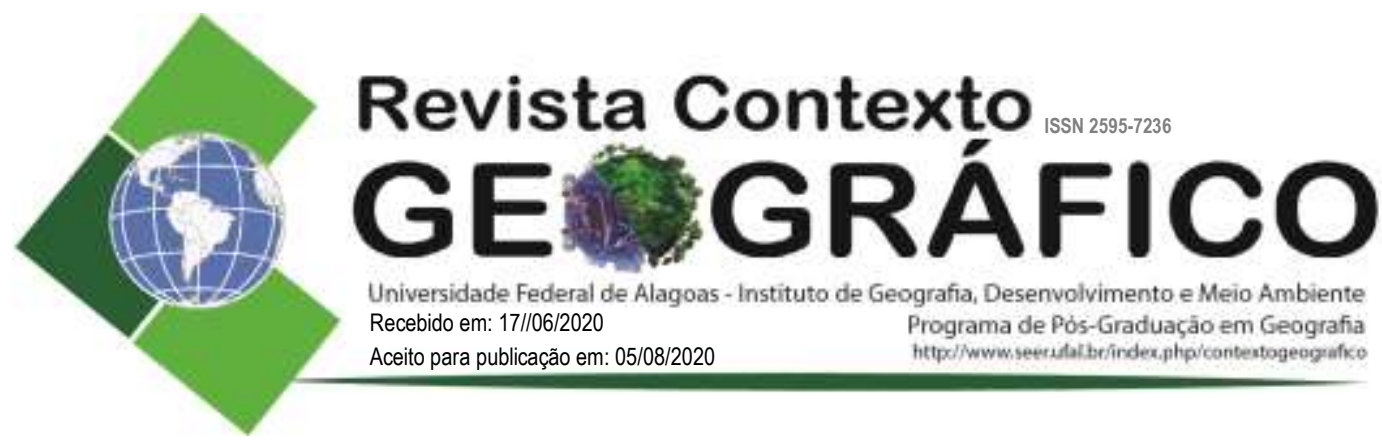

\title{
CIDADE SITIADA: MEDO, VIOLÊNCIA E INSEGURANÇA NAS ESCOLAS PÚBLICAS ESTADUAIS DE MANAUS
}

\author{
Ronaldo Souza Magalhães \\ Mestrando em Geografia da Universidade Federal do Amazona (UFAM), Amazonas, Brasil \\ ronaldomagalha@gmail.com \\ Nelcioney José de Souza Araújo \\ Doutor em Geografia da Universidade Federal do Amazona (UFAM), Amazonas, Brasil \\ nelcioneygeo@gmail.com
}

\begin{abstract}
RESUMO - A criminalidade cresce e sem dúvida é um grande problema social que historicamente atinge todos os segmentos da sociedade, manifestando-se de diversas formas, gerando impactos e consequências sociais. É sabido que locais onde existem grandes concentrações e movimentações de pessoas estão vulneráveis a ações criminosas capazes de comprometer a segurança do local. As escolas, por apresentarem essas características, estão, certamente, expostas a esses riscos e perigos. O reflexo da violência no meio escolar representa uma ameaça aos pilares fundamentais na formação das crianças e dos jovens, qual seja o sistema escolar. Os traumas deixados por quem já sofreu qualquer tipo de violência seja ela física, sexual, moral ou psíquica afetam não só a vida do cidadão, mas também de toda uma coletividade. Nessa perspectiva, a presente proposta tem como objetivo identificar e mapear as escolas públicas estaduais que foram alvos de roubos na cidade de Manaus nos anos de 2016 a 2018, além de coletar dados através de questionários e entrevistas aplicados aos profissionais da educação e da segurança pública para identificar os impactos na prática docente e quais as medidas têm sido tomadas para conter essas ações criminosas.
\end{abstract}

Palavras-chave: Criminalidade; Educação; Segurança Pública.

\section{BESIEGED CITY: FEAR, VIOLENCE AND INSECURITY IN PUBLIC SCHOOLS OF MANAUS}

\begin{abstract}
The criminality increases and undoubtedly it is a major social problem that historically affects all segments of society, manifesting itself in various ways, generating social impacts and consequences. It is well known that places where there are large concentrations and movements of people are vulnerable to criminal actions that could compromise the local safety. Schools, for presenting these characteristics, are certainly exposed to these risks and dangers. The reflection of violence in the school environment represents a threat to the fundamental pillars in the formation of children and young people, regardless of the school system. The traumas left by anyone who has suffered any kind of violence whether physical, sexual, moral or psychic affect not only the life of the citizen, but also of an entire community. From this perspective, the present proposal aims to identify and map the State Public Schools that were targets of robberies in the city of Manaus from 2016 to 2018, besides collecting data through questionnaires and interviews applied to Education and Public Safety Professionals to identify the impacts on teaching practice and what measures have been taken to contain these criminal actions.
\end{abstract}

Keywords: Criminality; Education; Public Security.

\section{INTRODUÇÃO}

A criminalidade cresce e sem dúvida é um grande problema social que historicamente atinge

$\begin{array}{llllll}\text { Revista Contexto Geográfico } & \text { Maceló-AL } & \text { V.5. N.10 } & \text { DeZembro/2020 } & \text { P. } 38-55 & \text { PÁGina } 38\end{array}$ 
todos os segmentos da sociedade, manifestando-se de diversas formas, gerando impactos e consequências sociais. Segundo (DURKHEIM, 2005) o crime não se observa só na maior parte das sociedades desta ou daquela espécie, mas em todas as sociedades de todos os tipos.

Nas diversas naturezas criminais destacam-se os crimes contra o patrimônio que é aquele cometido contra os bens móveis e imóveis ou contra a situação financeira de uma pessoa ou organização. Dentre suas tipificações, aponta-se o roubo como o crime de maior incidência no Brasil dessa natureza criminal. De acordo com o Código Penal Brasileiro (CPB), o roubo tratase de subtrair coisa móvel alheia para si ou para outrem, mediante grave ameaça ou violência a pessoa, ou depois de havê-la, por qualquer meio, reduzindo à impossibilidade de resistência (CPB, 2008). O roubo trata-se de crime contra o patrimônio em que é atingida, também a integração física ou psíquica da vítima.

É sabido que locais onde existem grandes concentrações e movimentações de pessoas estão vulneráveis a ações criminosas capazes de comprometer a segurança do local. As escolas, por apresentarem essas características, estão, certamente, expostas a esses riscos e perigos. Segundo dados do Fórum Brasileiro de Segurança Pública (FBSP) 40\% das escolas de todo o Brasil não possui esquema de policiamento para evitar violência em seu entorno, como furtos, roubos e outras formas de violência (FBSP, 2017).

A violência nas escolas trata-se de uma questão multicausal e complexa que demanda análises e estudos mais aprofundados. O reflexo da violência no meio escolar representa uma ameaça aos pilares fundamentais na formação das crianças e dos jovens, qual seja o sistema escolar.

Segundo a Organização Mundial da Saúde (OMS, 2002) a violência é definida como o "uso intencional da força ou poder em uma forma de ameaça ou efetivamente, contra si mesmo, outra pessoa, grupo ou comunidade, que ocasiona ou tem grandes probabilidades de ocasionar lesão, morte, dano psíquico, alterações do desenvolvimento ou privações". Os traumas deixados por quem já sofreu qualquer tipo de violência seja ela física, sexual, moral ou psíquica afetam não só a vida do cidadão, mas também de toda uma coletividade. Os profissionais da educação que vivenciaram esse tipo de violência são obrigados a desenvolver suas atividades em seu local de trabalho com a sensação de insegurança e medo.

Nessa perspectiva, a presente proposta tem como objetivo identificar e mapear as escolas públicas estaduais que foram alvos de roubos na cidade de Manaus nos anos de 2016 a 2018. Além de coletar dados através de questionários e entrevistas aplicados aos profissionais da educação e da segurança pública para identificar os impactos na prática docente e o que têm sido feito para conter essas ações criminosas.

\section{METODOLOGIA}

A construção do conhecimento científico exige uma série de etapas, etapas estruturadas pelos procedimentos metodológicos, equipamentos, recursos técnicos e tecnológicos usados durante uma pesquisa de campo para coleta de dados, além de materiais para gerar informações necessárias para produção de um dado conhecimento. São vários os métodos sugeridos pelas diversas ciências, elas conduzem a espaços intelectuais que se abrem à abordagem dos fenômenos e possibilitam o seu estudo. Para a realização do estudo utilizou-se aqui uma abordagem quantitativa e qualitativa dos dados.

Em um primeiro momento, uma abordagem quantitativa com base no banco de dados disponível no Sistema Integrado de Segurança Pública (SISP-AM) referente aos roubos nas escolas públicas estaduais no período de 2016 a 2018. Os dados foram disponibilizados através de boletins de ocorrências registrados pela Polícia Civil. Após a tabulação dos dados iniciou o processo de espacialização, que consiste em georreferenciar as ocorrências criminais relevantes ao estudo. 
A busca deste entendimento passa obrigatoriamente pela aplicação das técnicas de geoprocessamento. O autor (RODRIGUES, 1993) define Geoprocessamento como "um conjunto de tecnologias de coleta, tratamento, manipulação e representação de informações espaciais voltados para um objetivo específico."

Num segundo momento, uma abordagem qualitativa com base em questionários e entrevistas semiestruturadas aplicadas aos profissionais da educação nas escolas públicas estaduais vítimas ou não de roubos para apontar os impactos na prática docente. No total foram 67 profissionais da educação da rede estadual de ensino distribuído nas 12 escolas visitadas, sendo duas em cada zona da cidade de Manaus.

Também foram realizadas entrevistas semiestruturadas à dois profissionais da segurança pública, para verificar o que têm sido feito para conter os roubos nas escolas públicas estaduais.

\section{RESULTADOS E DISCUSSÃO POLÍTICAS PÚBLICAS DE SEGURANÇA NAS ESCOLAS}

A política pública é uma intervenção do Estado no âmbito social, através de instrumentos públicos ou determinações administrativas, no sentido de atender as necessidades sociais, interesses de grupos, gerenciar conflitos, por meios de programas, ações voltadas para setores específicos da sociedade. Segundo (RUA, 1998) políticas públicas são conjuntos de decisões e ações destinadas à resolução de problemas políticos.

Uma boa política pública é aquela que propõe dar respostas eficientes e eficazes aos problemas sociais, como por exemplo, a violência, além de fornecer serviços com qualidade e garantir os direitos dos cidadãos. Embora muitas das causas da violência estejam fora da escola, o seu reflexo no meio escolar representa uma ameaça considerável à formação das crianças e jovens, seja qual for o seu sistema.

Segundo a Constituição Federal Brasileira (CFB, 1988) compete a União, aos Estados e ao Distrito Federal legislar sobre a educação, proteção à infância e juventude. Desta forma, Estados e Municípios também podem criar suas próprias leis, detalhando no âmbito de suas competências, as medidas de segurança escolar cabíveis às realidades regionais do país.

$\mathrm{Na}$ esfera Estadual, é destaque como ponto frágil, segundo o Documento Base do Plano Estadual de Educação do Amazonas (PEEAM) de 2015, a necessidade de formulações de políticas para a superação da violência e problemas de segurança nas escolas e na sociedade (PEEAM, 2015). Diante dessa necessidade, alguns programas foram lançados com a ação conjunta entre a Secretaria de Educação (SEDUC) e a Secretaria de Segurança Pública (SSP).

Um desses programas foi o "Ronda Escolar", instituído em 2012, onde o foco é o patrulhamento ostensivo e preventivo nas unidades de ensino estaduais e municipais. O programa visa coibir assaltos e furtos a estudantes e educadores no entorno dos estabelecimentos educacionais, além de realizar palestras sobre diferentes temas aos estudantes.

Porém, sobre o Programa Ronda Escolar informou o Major (1) da Polícia Militar do Estado do Amazonas (PMAM): O programa está aí, ativo. No entanto, ele é mais forte em algumas áreas da cidade. Infelizmente, estamos com o efetivo bastante reduzido e não temos condições de atender a todas as escolas.

Durante a entrevista, o Major (1) da PMAM continuou: Existem áreas da cidade que são mais problemáticas que outras, então, devido ao baixo efetivo, temos que priorizar o atendimento as ocorrências de maior gravidade.

Existem outros programas desenvolvidos pela PMAM em parceria com a SEDUC/AM com foco na redução da violência no ambiente escolar. Programas como "Escola Segura e Cidadã" e o "Programa Educacional de Resistência às Drogas (PROERD)" procuram aproximar e fortalecer o trinômio: POLÍCIA, ESCOLA E FAMÍLIA.

Contudo, são ações isoladas que não acontecem em todas as zonas da cidade, mesmo sendo programas institucionais. Sobre isso o Major (1) da PMAM diz: Isso é gestão. O comandante da área tem que dar 
uma resposta ao seu superior. Se na sua área a incidência maior for de assaltos a coletivos, ele vai concentrar suas energias ali.

Dessa forma, as iniciativas são fragmentadas, desconectadas e descontínuas, seja por falta de efetivo ou pelo desinteresse da gestão.

\section{OS SISTEMAS DE SEGURANÇA}

A escola para se proteger cada dia se isola mais da comunidade, adotando medidas de proteção e segurança para conter os atos de violência, tais como: câmeras de vigilância, alarmes, muros altos, cercas eletrificadas, portão fechado, policiamento, os quais são priorizados em detrimento de intervenções de cunho educativo e social (SPÓSITO, 1998).

Atualmente as escolas públicas estaduais dispõem do Sistema Escolar Integrado de Vigilância do Amazonas (Seivam) responsável pelo monitoramento feito através de Circuito Fechado de TV (CFTV), alarmes de intrusão, fechadura eletrônica, botão do pânico, além de um canal direto com a Companhia Interativa Comunitária (CICOM) da área. Além desse sistema de segurança, possui também agentes de portaria que controlam a entrada e saída de pessoas no interior das instituições de ensino.

Perguntados aos profissionais da educação sobre a eficiência do sistema de segurança, no que se refere a furtos e arrombamentos, as opiniões foram divergentes: Não funciona. Tive a escola várias vezes arrombada. O sistema de deteç̧ão de movimentos não funcionou e tive que solicitar um agente de vigilância 24 horas para evitar mais arrombamentos (Diretor de Escola Pública Estadual na zona norte de Manaus).

Funciona. Houve uma situação que meu celular tocou tarde da noite, era a empresa de vigilância dizendo que o alarme da escola tinha disparado, mas que eles já estavam no local e não havia sinais de arrombamento (Diretor de Escola Pública Estadual na zona leste de Manaus).

Em relação sobre a eficiência do Sistema na prevenção a roubos, as opiniões foram unânimes: A partir do momento que eles colocam uma arma em sua cabeça ou uma faca em seu pescoço, não há mais nada a ser feito (Diretor de Escola Pública Estadual na zona sul de Manaus).

Sobre o canal de comunicação direta com o Departamento Integrado de Polícia (DIP) da área, as respostas foram todas positivas: Sempre que precisamos, eles logo apareceram (Diretor de Escola Pública Estadual na zona centro-sul de Manaus).

Durante as visitas realizadas nas escolas públicas estaduais, foram feitas algumas observações, relevantes para a segurança nas escolas. Dentre elas, foi verificada a falta de um padrão de abordagem dos agentes de portaria, onde em 12 escolas visitadas, apenas uma solicitou algum documento de identificação. Nas demais, foi necessário apenas informar com quem gostaria de falar ou somente aparecer no portão para ter acesso ao interior da escola.

Outra importante observação foi a localização do botão do pânico nas escolas. Em 10 das 12 escolas visitas o botão do pânico localizava-se na sala do diretor, onde não há visibilidade externa, janelas por exemplo. Desta forma, não há como identificar uma situação de perigo para acionar o mecanismo de segurança.

\section{ANÁLISE DOS DADOS}

Os dados coletados na SSP/AM apresentam o quantitativo de ocorrências de roubos registrados nas escolas públicas estaduais de Manaus, nos anos de 2016 a 2018. Após a coleta e tabulação, os dados se apresentaram de uma maneira mais clara para uma análise mais eficaz.

Segundo a SSP-AM, houve um considerável aumento das ocorrências de roubo nas instituições de ensino públicas nos últimos três anos (Figura 1).

Os roubos as escolas públicas estaduais na cidade de Manaus, experimentaram um crescimento no período entre 2016 a 2017 de 53 ocorrências e no período que compreende os anos de 2017 a 2018 esse crescimento foi de 35 ocorrências, respectivamente $46 \%$ e $21 \%$. No total foram registradas 483 ocorrências nos últimos três anos. 
Figura 1. Roubo nas escolas públicas estaduais da Cidade de Manaus entre os anos de 2016 a 2018.

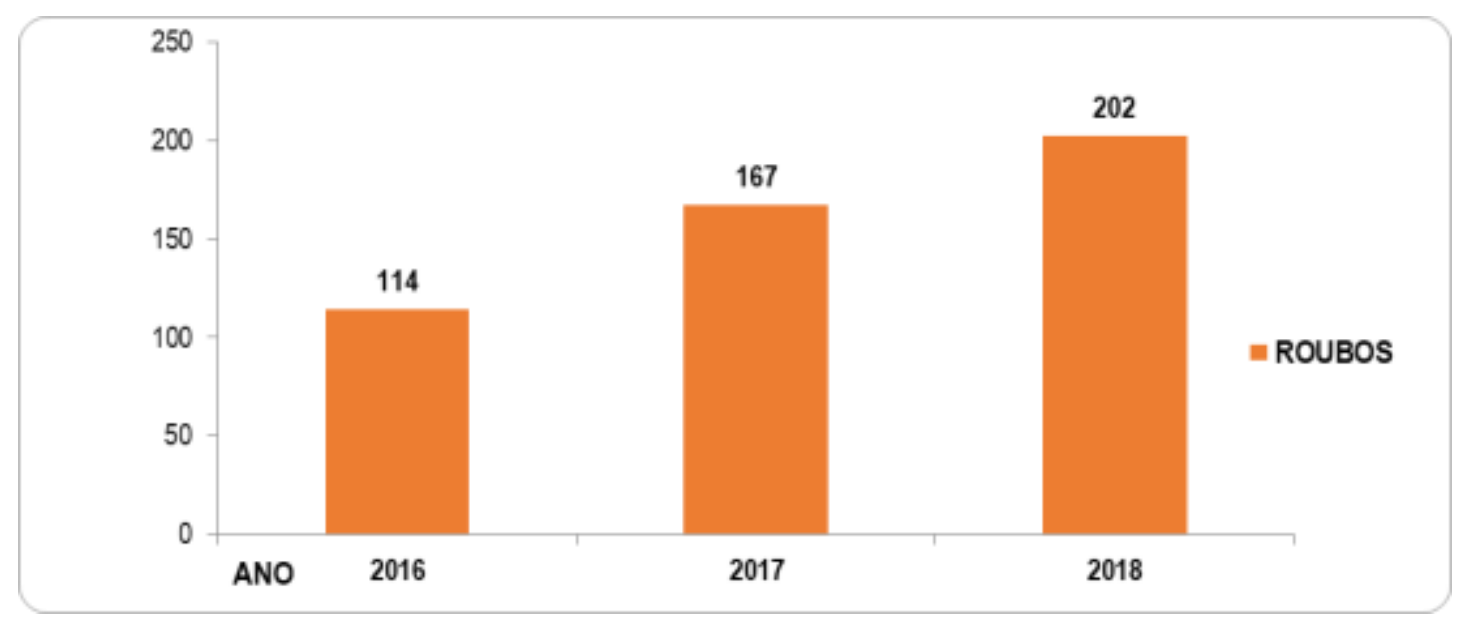

Elaboração: Os Autores (2019)

Segundo (TAVARES, 2012) as estatísticas criminais surgiram a partir da necessidade de se obter dados que possam subsidiar a tomada de decisões dos órgãos governamentais responsáveis pela segurança pública. Sendo assim, é necessário conhecer a dinâmica dessas práticas criminais, como dia (Figura 02) e horário (Figura 03), para traçar ações a fim de combatê-las.

Figura 2. Registros de roubo nas escolas públicas estaduais na cidade de Manaus por dia da semana

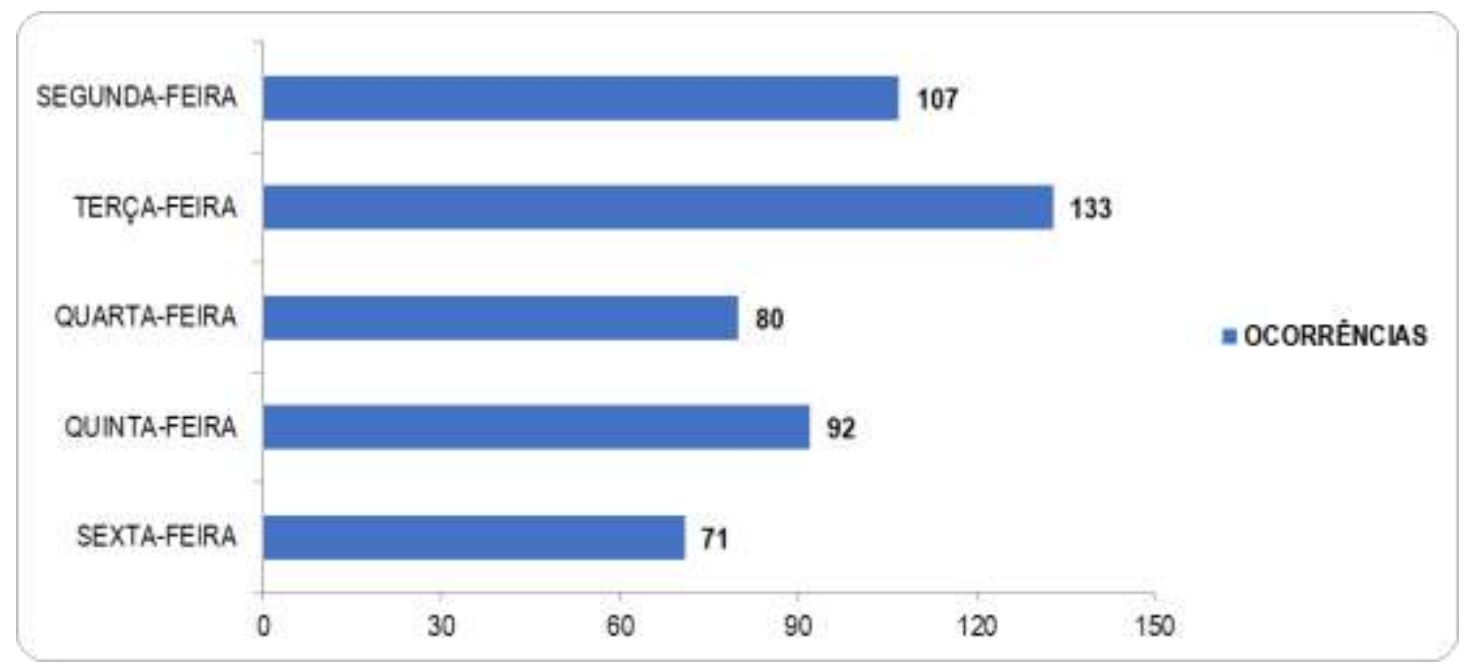

Elaboração: Os Autores (2019)

Na Figura 02 é possível identificar que as terças e as segundas-feiras são os dias da semana que mais ocorrem roubos nas escolas, ultrapassando mais de 100 registros cada um. $\mathrm{O}$ dia da semana que esses crimes têm a menor frequência é nas sextas-feiras com 71 registros.

Diante do exposto não foi percebido uma relação dos roubos com os dias da semana, pois as escolas possuem em todos os dias, a mesma quantidade de pessoas ou bens, ao contrário de outras instituições ou estabelecimentos que em determinados dias possuem um fluxo maior de pessoas ou bens, como bancos ou bares. 
Figura 3. Horário das ocorrências de roubo as escolas públicas estaduais na cidade de Manaus

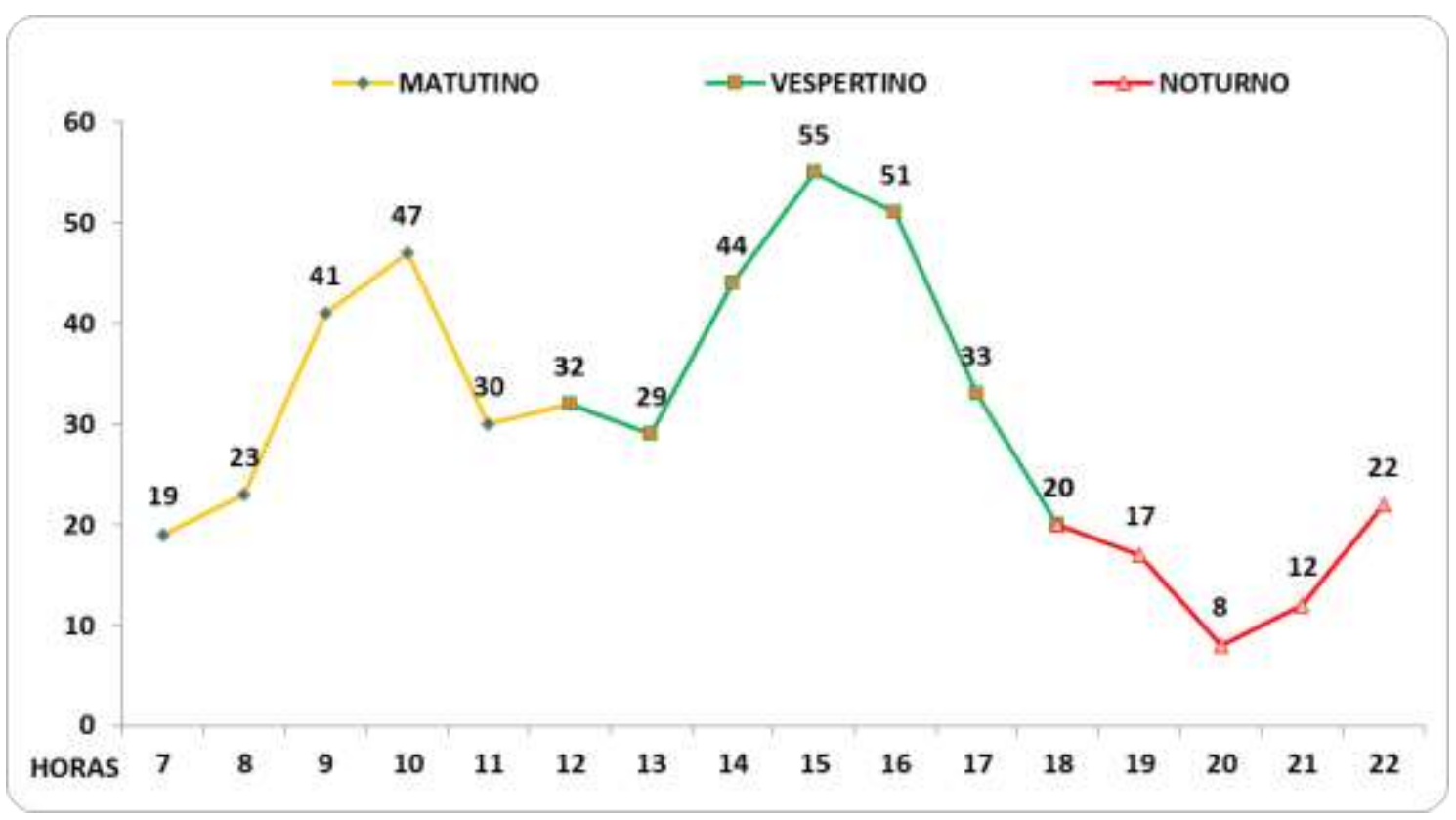

Elaboração: Os Autores (2019)

Para análise da Figura 03, é necessário destacar os horários dos turnos de funcionamento das escolas públicas estaduais de Manaus. As escolas estaduais funcionam em alguns casos em três turnos, sendo o matutino das $07 \mathrm{hs}$ às $11 \mathrm{~h} 15$, o vespertino das $13 \mathrm{hs}$ às $17 \mathrm{~h} 15$ e o noturno das $19 \mathrm{hs}$ às $22 \mathrm{~h} 15$. Existem ainda as escolas que funcionam em tempo integral, que nesse caso seu funcionamento é das $07 \mathrm{hs}$ às $16 \mathrm{hs}$.

Assim, o turno matutino apresenta 160 registros, o vespertino, com a maior quantidade de registros apresenta 244 e o noturno 79 registros. Percebe-se que os períodos que menos ocorrem os roubos estão compreendidos nos horários de entrada e saída de cada turno, salvo o turno noturno que apresenta a maior incidência de registros de roubos no horário de saída dos alunos.

Nesses horários, pais e alunos aglomeram-se nos portões das escolas gerando uma grande concentração de pessoas. Devido essa maior concentração, algumas escolas recebem nesses horários o apoio policial, seja de forma ostensiva (fixa em frente à escola ou na parada de ônibus mais próxima) ou percebida (rondas durante esse período), inibindo as ações criminosas.

Mesmo assim, há registros de ocorrências de roubos nesses horários. Eu sempre vejo uma viatura em frente a Escola nos horários de entrada e saída (Pedagoga de Escola Pública Estadual na zona centro-sul de Manaus). Sempre peço para os alunos andarem em grupos, pois a parada é distante e o entorno é perigoso (Pedagoga de Escola Pública Estadual zona norte de Manaus).

Os horários que mais incidem os roubos estão entre 09 e 10 da manhã e entre $14 \mathrm{hs}$ e $16 \mathrm{hs}$, juntos concentram 238 registros, equivalente a quase 50\% de todas as ocorrências. Uma hipótese para essas práticas ocorrerem nesses horários, deve-se ao fato de não haver movimentação de entrada e saída de pais e alunos nas escolas, ao contrário do início e fim de cada turno. Já fui assaltada algumas vezes quando saio a tarde. Hoje peço um mototáxi pra ir até a rua principal (Secretaria de Escola Pública Estadual na zona oeste de Manaus).

Nesses horários, o entorno das escolas geralmente fica vazios (Figuras 04 e 05), consequentemente o policiamento passa a ser feito através de rondas esporádicas. Um cenário perfeito para práticas criminais. 
Figura 4. Entorno de uma escola pública na zona norte da cidade de Manaus às $09 \mathrm{hs} \mathrm{da}$ manhã.

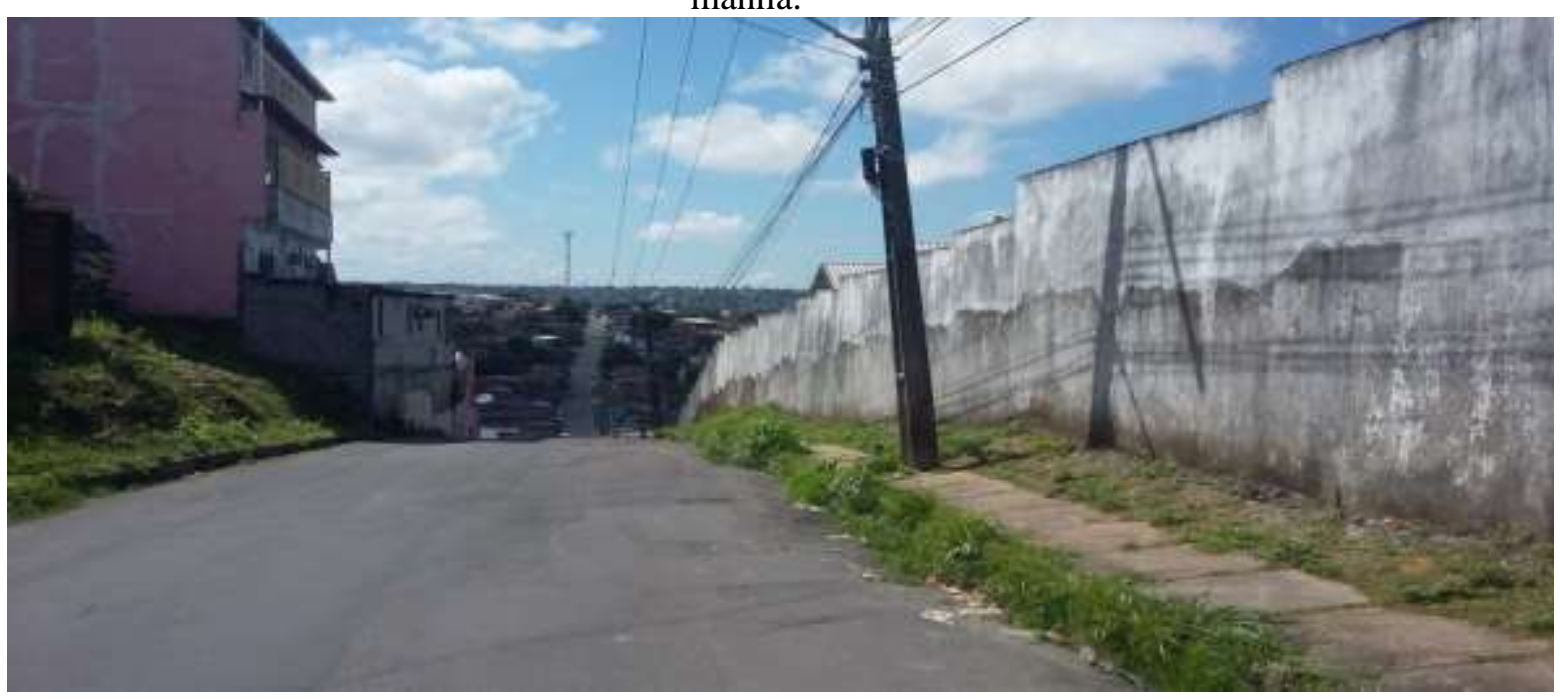

Fonte: Os Autores (2019)

Figura 5. Entorno de uma escola pública estadual na zona oeste da cidade de Manaus às $15 \mathrm{hs}$ da tarde.

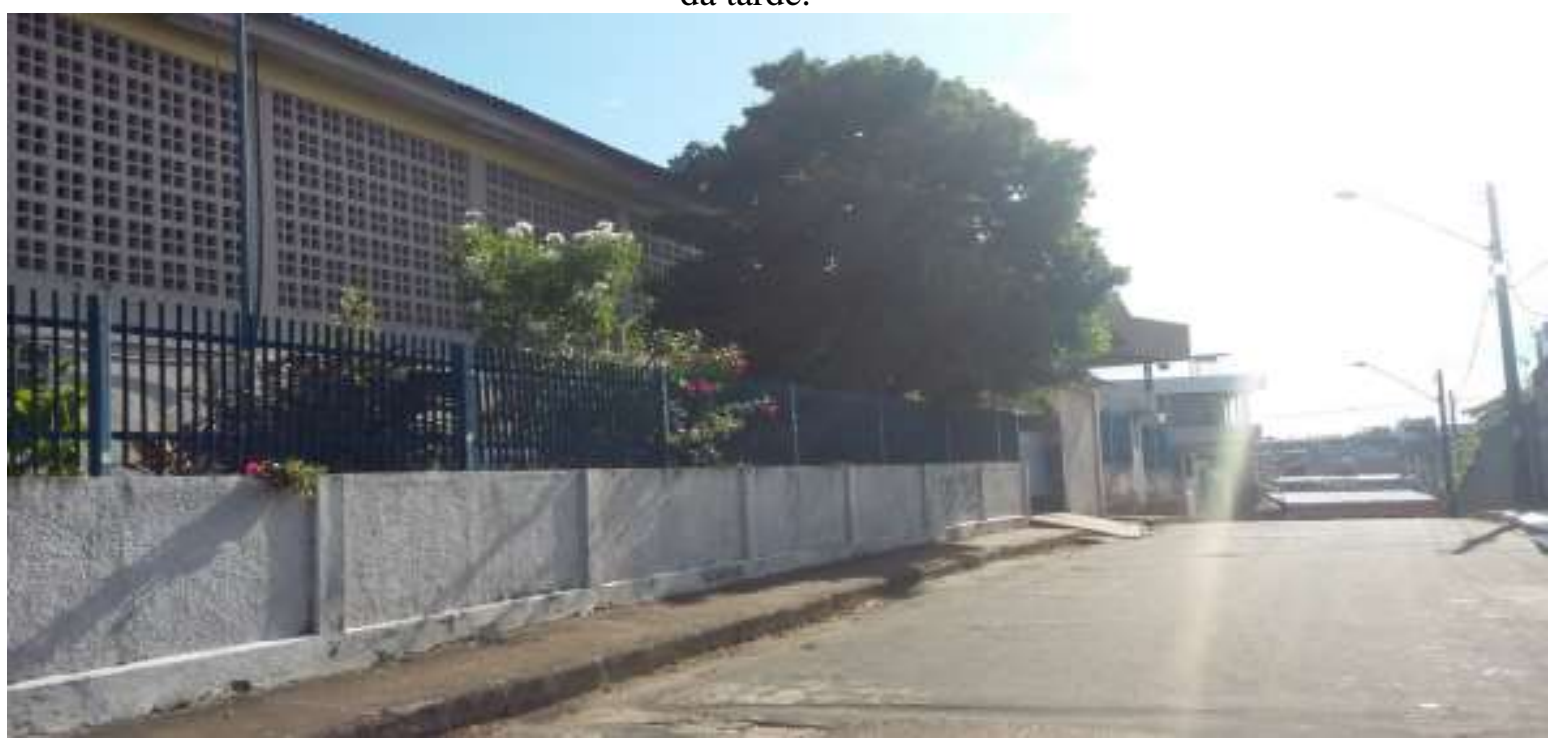

Fonte: Os Autores (2019)

Conhecendo os dias e horários de maior incidência de roubos as escolas públicas estaduais, é necessário então saber onde essas práticas criminais acontecem

\section{SISTEMAS DE INFORMAÇÕES GEOGRÁFICAS E MAPEAMENTO CRIMINAL}

Segundo (CÂMARA, 2005), os Sistemas de Informação Geográfica (SIG), correspondem às ferramentas computacionais de Geoprocessamento, que permitem a realização de análises complexas, ao integrar dados de diversas fontes e ao criar bancos de dados georreferenciados. A utilização dos SIGs na Segurança Pública, pode de forma atualizada identificar regiões de maiores ocorrências criminais e assim direcionar melhor as ações do estado para a distribuição do efetivo policial.

Assim, a aplicação dos SIGs, aparece como uma ferramenta de auxílio na análise de dados 
espaciais e na representação dos objetos geográficos de estudo. Quando se discute o espaço, é preciso tentar encontrar uma interpretação ou compreensão deste e o que o cerca. Sendo assim pode-se analisar a criminalidade como um fenômeno que está distribuído no espaço.

A análise criminal torna-se então um processo sistemático direcionado as informações sobre características e padrões de crimes, com o intuito de apoiar o Sistema de Segurança, que vai desde a distribuição de patrulhamento até a prevenção criminal. Com os dados inseridos é possível sua representação por meio de gráficos e tabelas, e ainda por mapas que permite a visualização deste espaço geográfico de forma georreferenciada.

Apesar dos enormes avanços e aperfeiçoamento das técnicas de mapeamento, faz se necessário lembrar que os mapas são elaborados a partir de dados e não devem ser compreendidos como uma cópia da realidade. $\mathrm{O}$ mapa é apenas uma ferramenta de análise utilizada para representar a distribuição espacial de um determinado fenômeno, especificamente nas ocorrências criminais, auxiliando na elaboração de estratégias na análise dos padrões criminais.

No caso dos dados criminais, a representação das áreas que concentram um número elevado de ocorrências é chamado de hot spots (zonas quentes). Os autores (WILSON e SMITH, 2008) chamam a atenção para a importância da detecção dos hot spots do crime, pois é através deles que é possível direcionar os esforços de policiamento e prevenção da criminalidade. Para gerar um mapa que permita essa identificação dos hot spots é recomendável o uso da ferramenta Kernel presente em softwares como ArcGis ou Qgis. Essa ferramenta permite a estimação de uma superfície de densidade a partir da distribuição de pontos.

Á seguir, têm-se a distribuição dos roubos as escolas públicas estaduais na cidade de Manaus nos anos de 2016 a 2018 (Figura 06). Buscou-se determinar as zonas administrativas que possuem a maior concentração de registros de roubos as escolas. A densidade dessa concentração está representada em três níveis: baixa, média e alta, sendo a alta apontada na cor vermelha identificando os hot spots.

Percebe-se que existem três áreas que apresentam uma maior concentração de registros (hot spots). Os hot spots estão localizados nas Zonas Norte e Leste, sendo dois na Zona Norte e um na Zona Leste. Nota-se que existe um corredor que liga esses hot spots variando entre os três níveis de concentração que se estende da Zona Norte à Zona Leste.

A criminalidade está ligada a diversos fatores, que vão desde problemas econômicos, demográficos, exclusões sociais e até por problemas psicológicos, sendo assim um tema multifacetado. Todavia, há uma relação entre criminalidade e densidade demográfica. Alguns autores defendem que áreas com um elevado número populacional estão positivamente associadas a um maior número potencial de vítimas, proporcionando um alto retorno para crimes patrimoniais, como o roubo (GLAESER e SACERDOTE, 1999).

Assim sendo, segundo o (IBGE, 2010 as regiões administrativas mais populosas são as Zonas Norte e Leste com 521.000 e 466.000 habitantes respectivamente, exatamente as que apresentaram os hot spots de roubos as escolas públicas estaduais.

O mapa mostra ainda que existe uma quantidade relevante de registros em parte da Zona Sul e Centro-Oeste alterando entre baixa e média os níveis de concentração. As Zonas Oeste e Centro-Sul apresentam baixas concentrações de ocorrências desse tipo de crime.

Evidencia-se que as zonas norte e leste como as que possuem a maior quantidade de registros de roubos as escolas públicas estaduais, consequentemente são as zonas que possuem os hot spots, com 321 registros no total. A quantidade desses registros nessas duas zonas representa aproximadamente $66 \%$ do total de ocorrências nos últimos três anos. A zona Centro-Sul aparece como a zona de menor incidência dessa prática criminal com 20 registros (Tabela 1). 
Figura 6. Mapa de Kernel sobre roubos as escolas públicas estaduais de Manaus de 2016 a 2018.

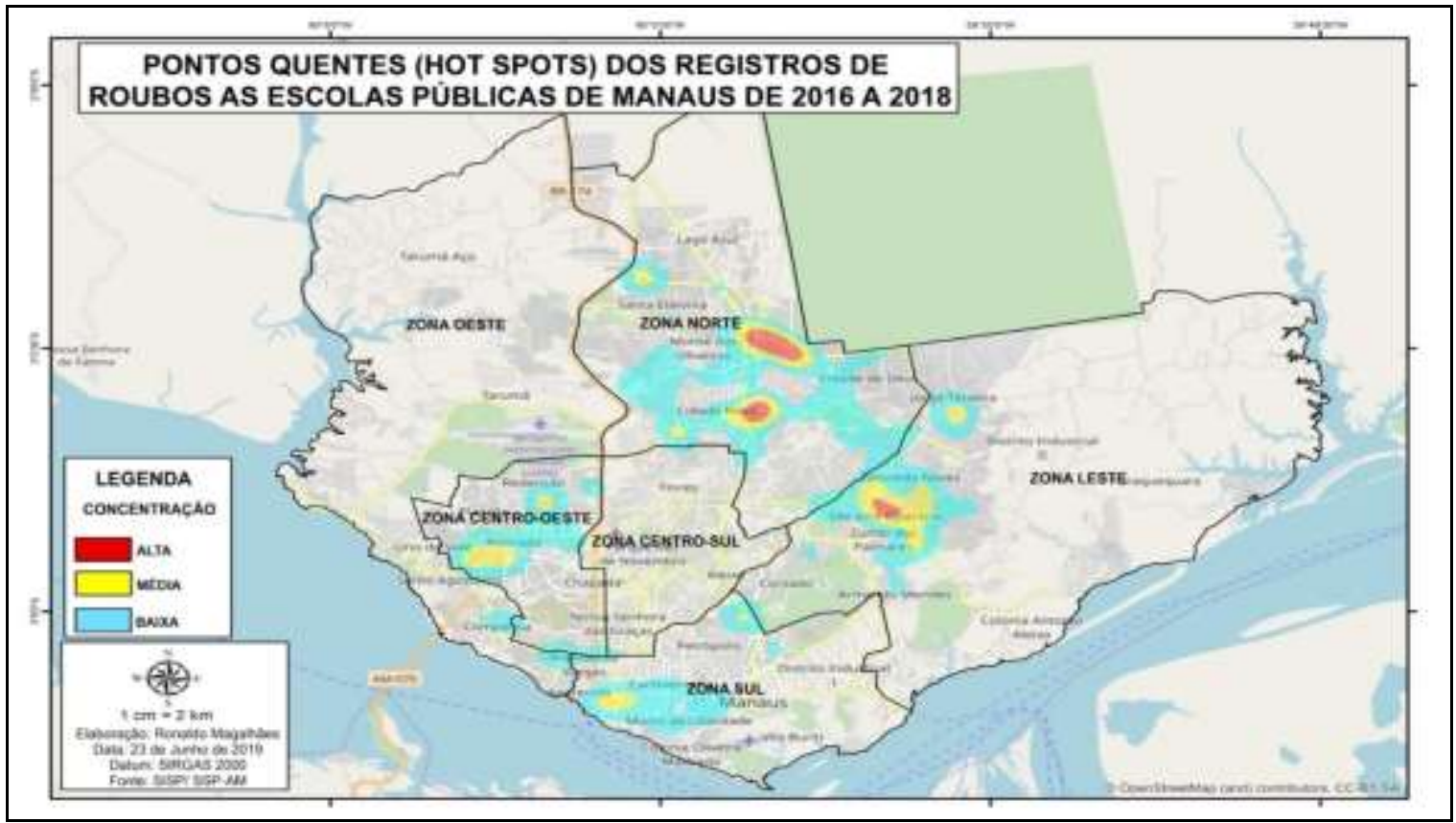

Elaboração: Os Autores (2019)

Tabela 1. Quantidade de registros de roubos por zonas administrativas

\begin{tabular}{l|l}
\hline Zona & Registros \\
\hline Norte & 199 \\
\hline Leste & 122 \\
\hline Sul & 69 \\
\hline Centro-Oeste & 41 \\
\hline Oeste & 32 \\
\hline Centro-Sul & 20 \\
\hline
\end{tabular}

Elaboração: Os Autores (2019)

\section{MODUS OPERANDI}

Dada à relevância de compreender a ação criminosa e os fatores que a envolvem, revela-se fundamental analisar seu modus operandi, ou seja, como se dão as ações dos criminosos. Para compreender o modus operandi dos crimes de roubos, foi necessário ler os boletins de ocorrência registrados no Sistema Integrado de Segurança Pública referente aos crimes de roubos praticados nas escolas públicas estaduais de Manaus. A partir da análise descritiva das ocorrências, foi possível identificar o modo como os assaltantes agem, o meio empregado e o número de envolvidos.

No que diz respeito ao modus operandi, os autores do crime de roubo as escolas públicas estaduais de Manaus geralmente agem em dupla. Enquanto um entra e pratica o ato criminoso, um segundo fica do lado de fora dando cobertura para esse primeiro. Dois chegaram e um me mostrou a arma enquanto o outro foi em direção à sala dos professores (Monitor de Escola Pública Estadual na zona sul de Manaus).

A motocicleta é predominantemente utilizada para essa prática criminal, porém há registros de roubos terem sido cometidos a pés. $\mathrm{O}$ emprego de armas de fogo é frequente nesses crimes, também há registros de utilização de armas brancas (facas ou canivetes). Essas armas são utilizadas para render e amedrontar as vítimas. Estávamos na quadra, quando percebi já estavam pulando o muro, um veio em minha direção e colocou uma faca no meu pescoço, enquanto os outros tomavam os pertences dos alunos durante a Educação Física (Professora de Escola Pública Estadual na zona oeste de Manaus). 
O modo que os criminosos têm acesso ao interior das escolas é variado. Há registros de emprego de violência, onde armados os criminosos rendem os agentes de portaria ou os próprios funcionários das escolas, acessam seu interior pelo portão principal e praticam o crime. Apesar das escolas públicas estaduais possuírem fechaduras eletrônicas, eles aproveitam o horário de entrada e saída dos alunos, momento que o portão externo (Figura 07) está aberto, para invadir, render o agente de portaria, passar pelo portão interno (Figura 08) e praticar o roubo.

Figura 7. Portão principal (externo) de uma escola pública estadual na zona oeste da Cidade de

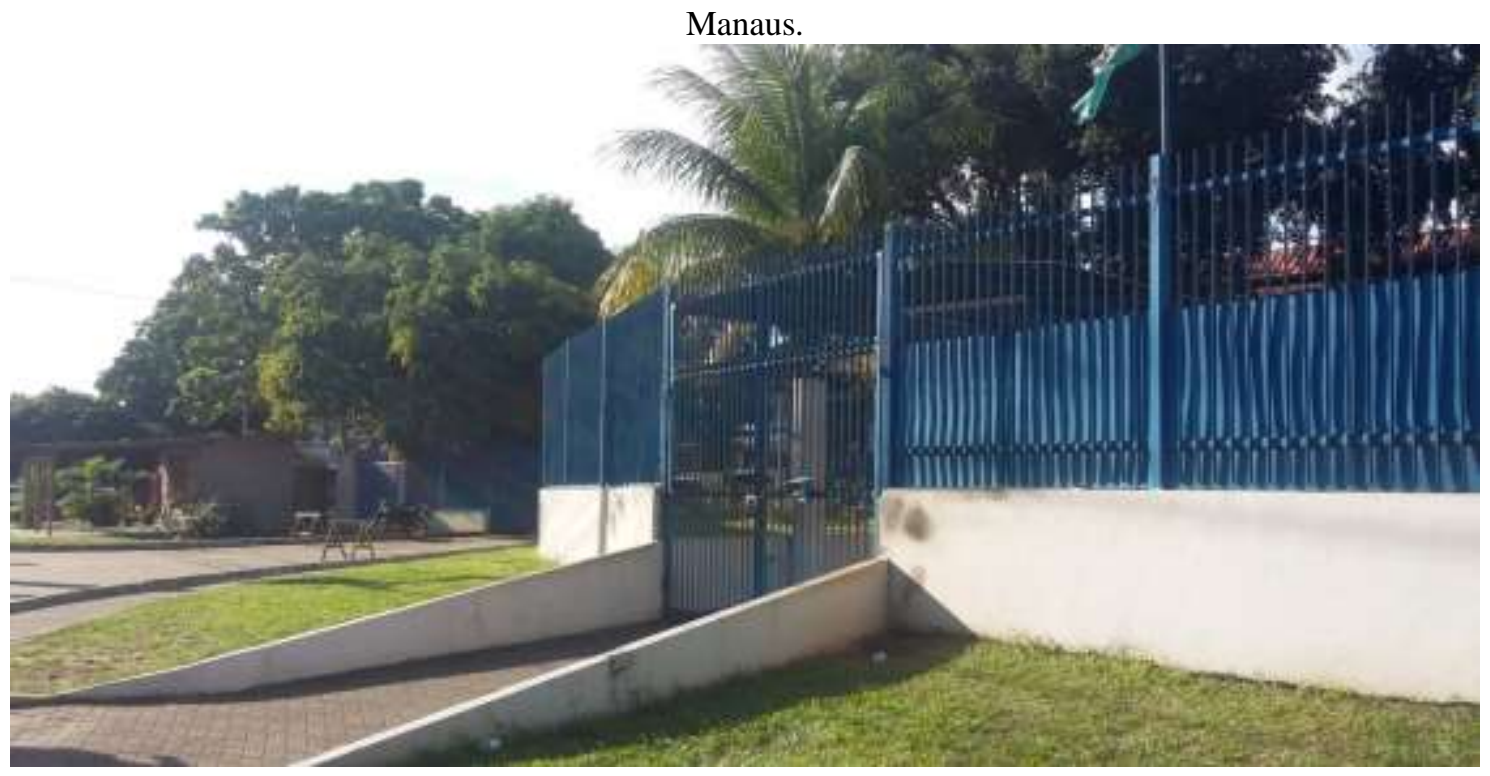

Fonte: Os Autores (2019)

Figura 8. Portão interno de uma escola pública estadual na zona norte da Cidade de Manaus.

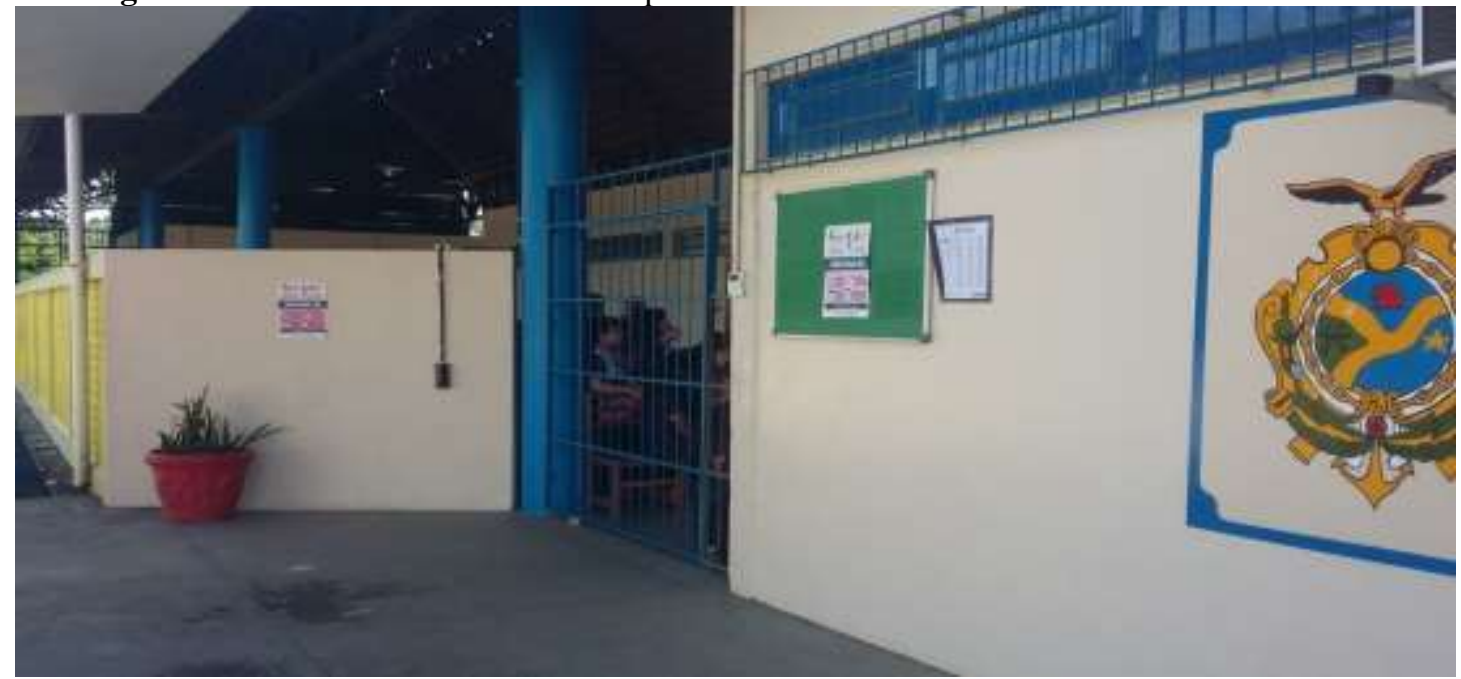

Fonte: Os Autores (2019)

Vale ressaltar que nas visitas realizadas, foi percebido que nem todas as escolas públicas estaduais possuem o portão interno. Essas escolas dispõem somente do portão externo para separar do interior da escola. Porém, de acordo com a leitura dos boletins de ocorrências, evidenciou-se que a forma mais utilizada pelos criminosos para entrar nas escolas é pulando os muros laterais, que geralmente são baixos, sem proteção e sem vigilância (Figura 09). 
Figura 9. Muro baixo e sem proteção em uma escola pública estadual na zona norte da Cidade de Manaus.

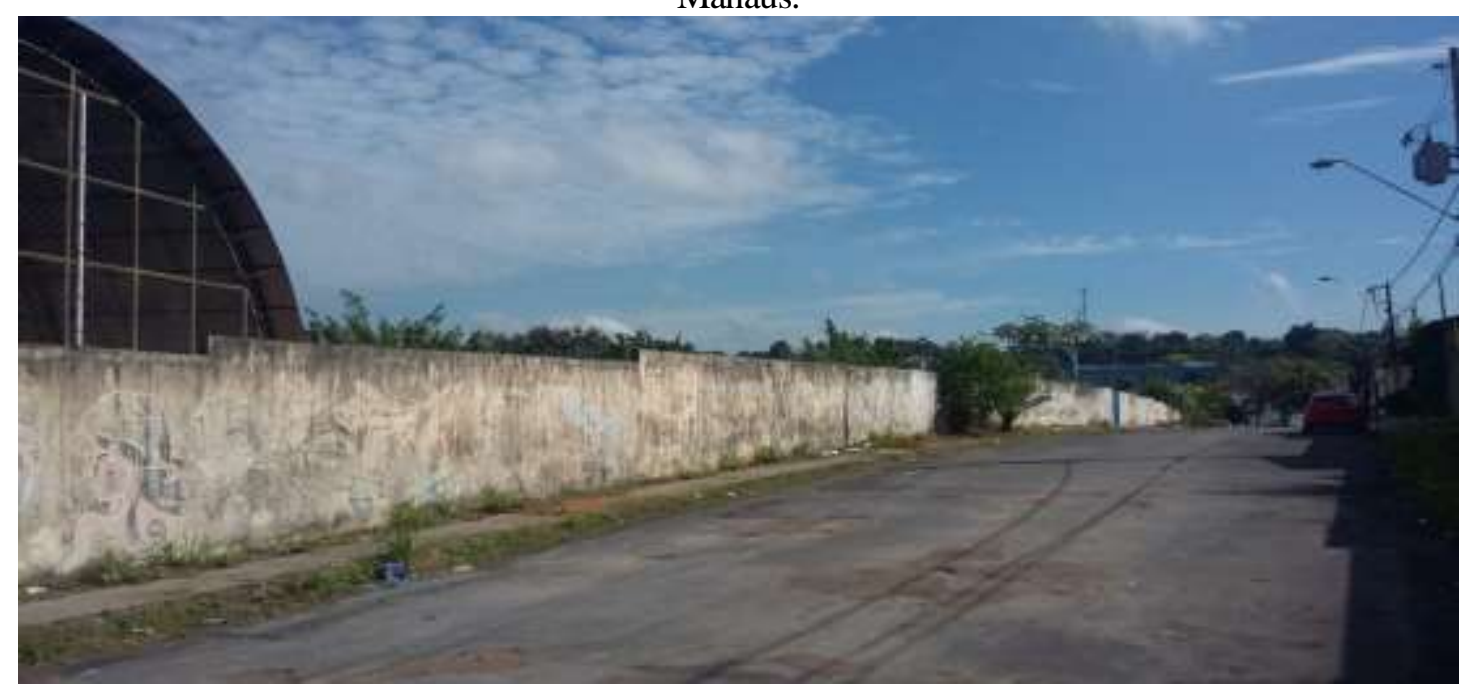

Fonte: Os Autores (2019)

Eu estava em minha sala quando percebi uma movimentação no corredor. Foi quando me contaram que a Escola tinha acabado de sofrer um arrastão. Bandidos pularam o muro de uma das laterais, renderam o agente de portaria e foram em algumas salas para levar os pertences de alunos e professores (Diretor de Escola Pública Estadual na zona centro-oeste de Manaus).

Foi observado durante as visitas que algumas escolas possuem cercas de proteção do tipo helicoidal (Figura 10) ou do tipo arame farpado (Figura 11) nos muros para evitar invasões.

Figura 10. Cerca de proteção do tipo helicoidal em uma escola pública estadual na cidade de Manaus.

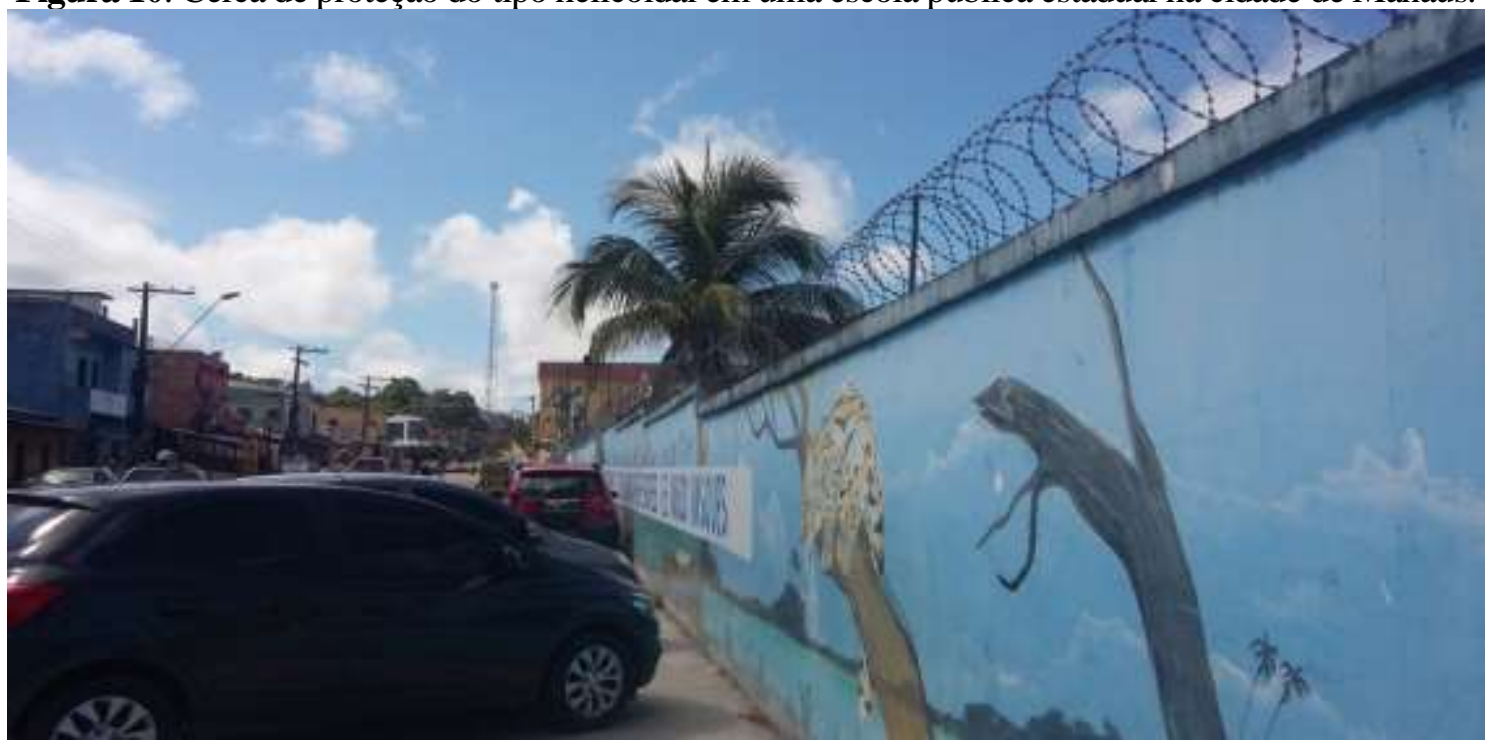

Fonte: Os Autores (2019) 
Figura 11. Cerca de proteção do tipo arame farpado em uma escola pública na cidade de Manaus.

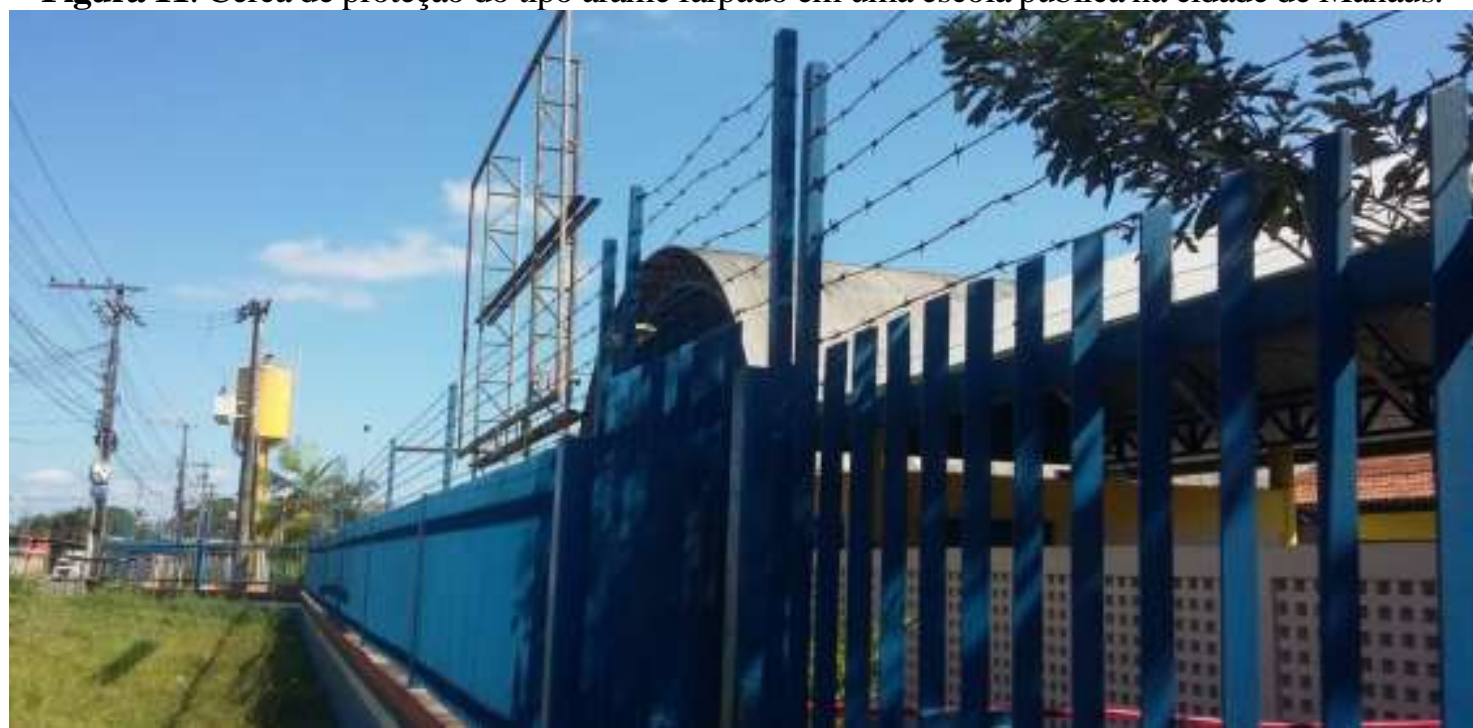

Fonte: Os Autores (2019)

Tive que solicitar a cerca de proteção, pois as invasões eram constantes (Diretor de Escola Pública Estadual na zona leste).

Os modus operandi apresentados são recorrentes nos três períodos de funcionamento das escolas, porém existe uma peculiaridade no período noturno. Por não exigir a obrigatoriedade do uniforme no período noturno, a SEDUC/AM permite a entrada dos alunos vestindo uma calça jeans e uma blusa branca. Dessa forma, os bandidos conseguem adentrar nas dependências escolares sem nenhuma dificuldade disfarçados de alunos. Eu tenho no período noturno mais de 500 alunos que frequentam a Escola, é impossível identificar quem é aluno e quem não é (Diretor de Escola Pública Estadual na zona leste de Manaus).

Diante do que foi demonstrado, a análise revelou, que em sua maioria, o sistema de segurança nas escolas públicas estaduais apresenta-se ineficiente e como consequência deixa expostos aqueles que em seu dia-a-dia dependem dele.

\section{MEDO, INSEGURANÇA E SUAS IMPLICAÇÕES NA PRÁTICA DOCENTE}

O reflexo da violência no meio escolar representa uma ameaça aos pilares fundamentais da formação das crianças e dos jovens, qual seja o sistema escolar. Para (TEIXEIRA, 1998), a profissão docente comporta um forte envolvimento humano, exigindo condições adequadas para se realizar, incluindo nessas condições a tranquilidade. Contudo, os Profissionais da Educação, em sua maioria, atuam num ambiente inseguro fazendo com que o medo predomine.

Como parte das atividades desse trabalho, foram aplicados questionários e realizadas entrevistas, com o intuito de obter informações mais precisas da realidade sob a ótica daqueles que de alguma forma foram vítimas ou não de roubos nas escolas públicas estaduais. Segundo (MINAYO, 2009) assegura que o trabalho de campo permite a aproximação do pesquisador da realidade sobre a qual se formulou uma pergunta e também estabelece uma relação com os "atores" que conformam a realidade.

Ao todo 67 profissionais da educação responderam ao questionário. A quantidade foi determinada pelas oportunidades geradas durante o trabalho de campo. Muitas foram as dificuldades encontradas na coleta dos dados em campo, mas o principal obstáculo foi o medo, o receio das pessoas em fornecer quaisquer informações sobre a segurança.

A maioria das informações coletadas foi conseguida mediante a apresentação de declarações e 
minuciosas explicações do intuito do trabalho. Houve algumas recusas, pois a desconfiança no outro prevalece, principalmente numa cidade dominada pelo medo e pela insegurança. A sistematização dos dados coletados através do questionário revelou importantes informações para a pesquisa.

Quanto a vitimização, $42 \%$ dos profissionais da educação já foram vítimas de roubos nas escolas que atuam, enquanto 58\% não foram vítimas dessa prática criminal (Figura 12).

Figura 12. Gráfico em relação a quanto a ser vítima de roubos em escolas públicas estaduais de Manaus.

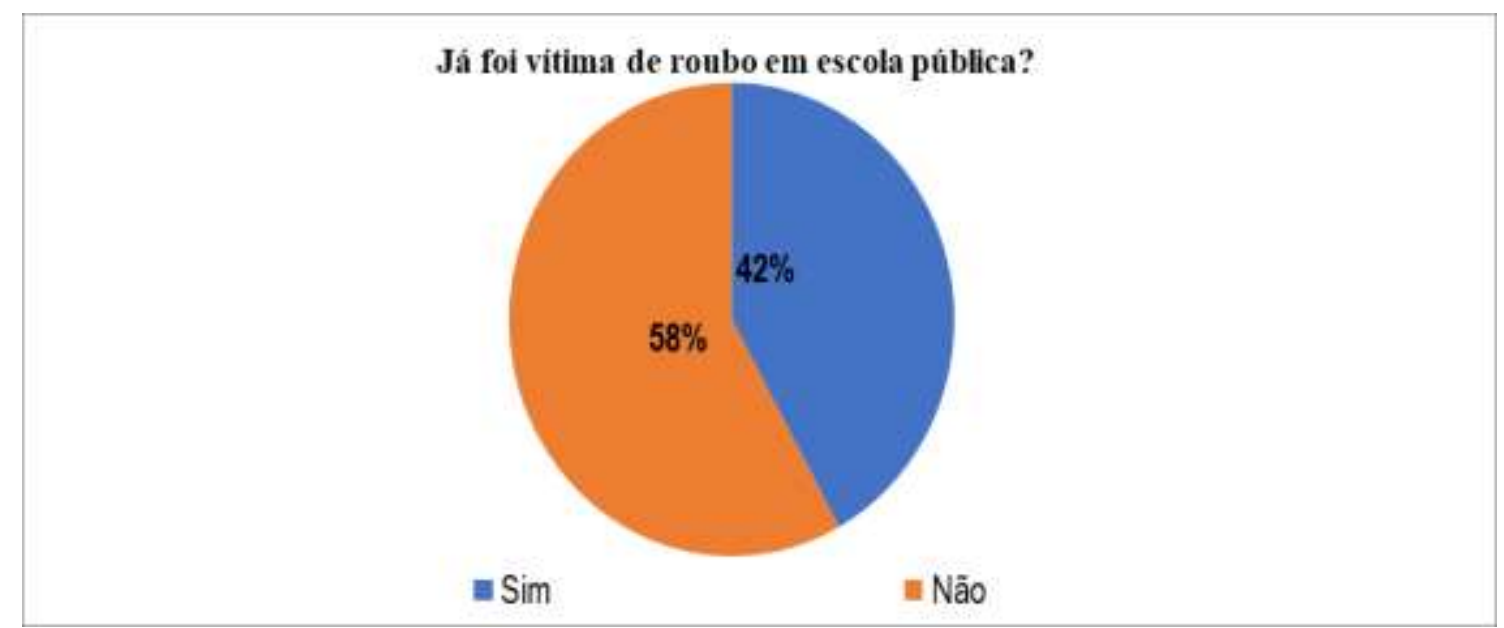

Elaboração: Os Autores (2019)

Durante a aplicação do questionário e das entrevistas foi possível coletar alguns relatos. Tinha acabado de entrar em sala, coloquei minha bolsa na mesa, quando eles entraram na sala anunciando o assalto (Professora de Escola Pública Estadual na zona oeste de Manaus).

Eu estava atendendo um pai de um aluno, quando ele chegou e apontou a arma pedindo meu celular (Secretaria de Escola Pública Estadual na zona centro-oeste de Manaus).

Em relação a ter presenciado roubo em escolas públicas estaduais, o gráfico 05 revela que $72 \%$ já presenciaram essa prática criminal e que $18 \%$ nunca testemunharam.

Figura 13. Gráfico em relação sobre ter presenciado roubos em escolas públicas estaduais de Manaus.

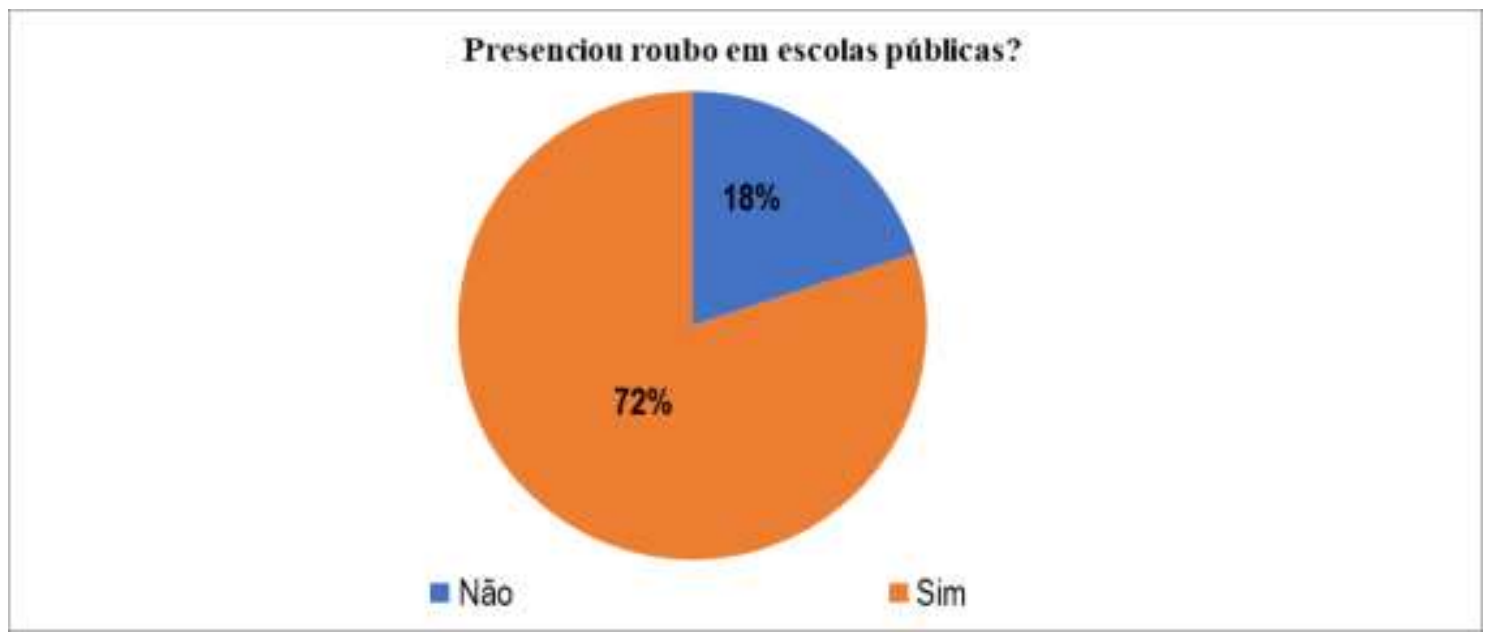

Elaboração: Os Autores (2019) 
MAGALHÃES, R. S.; ARAÚJO, N. J. S..
CIDADE SITIADA: MEDO, VIOLÊNCIA E INSEGURANÇA NAS ESCOLAS PÚBLICAS

ESTADUAIS DE MANAUS

Diante do exposto, fica evidente que a violência passou a fazer parte do cotidiano dos profissionais da educação, a maioria já passou ou presenciou os roubos ocorridos nas escolas públicas estaduais.

Quanto a se sentir seguro(a) na escola que trabalha, a maioria respondeu não (Figura 14).

Figura 14. Gráfico quanto a se sentir seguro na escola que trabalha?

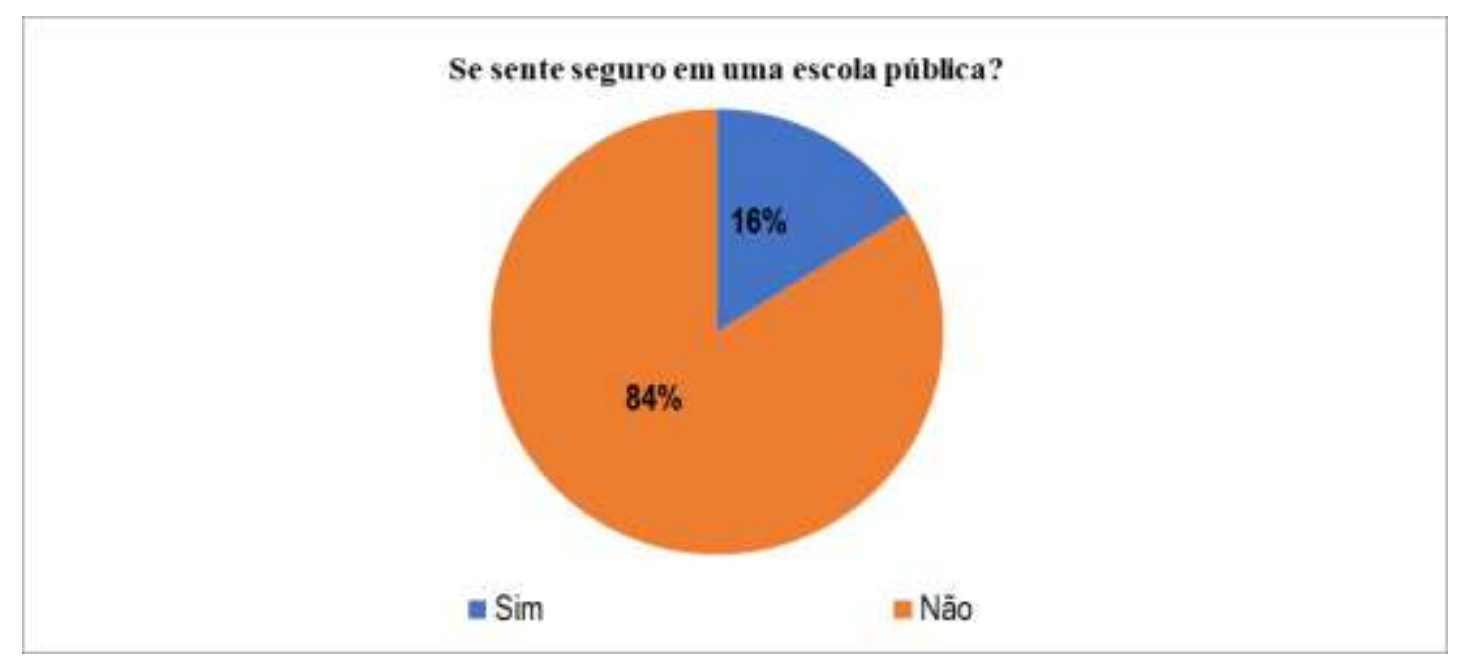

Elaboração: Os Autores (2019)

Quando perguntado, se já foi vítima de roubo no entorno da escola onde trabalham, $91 \%$ responderam não, porém muitos profissionais da educação disseram ter presenciado ou ter conhecimento de diversos assaltos nos arredores. Esse alto índice na resposta a questão deve-se ao fato de muitos possuírem veículo próprio e também de muitas escolas disporem de estacionamento em seu interior, dessa forma não fazem uso do seu entorno (Figura 15).

Figura 15. Gráfico em relação a ter sido vítima de roubo no entorno da escola onde trabalha.

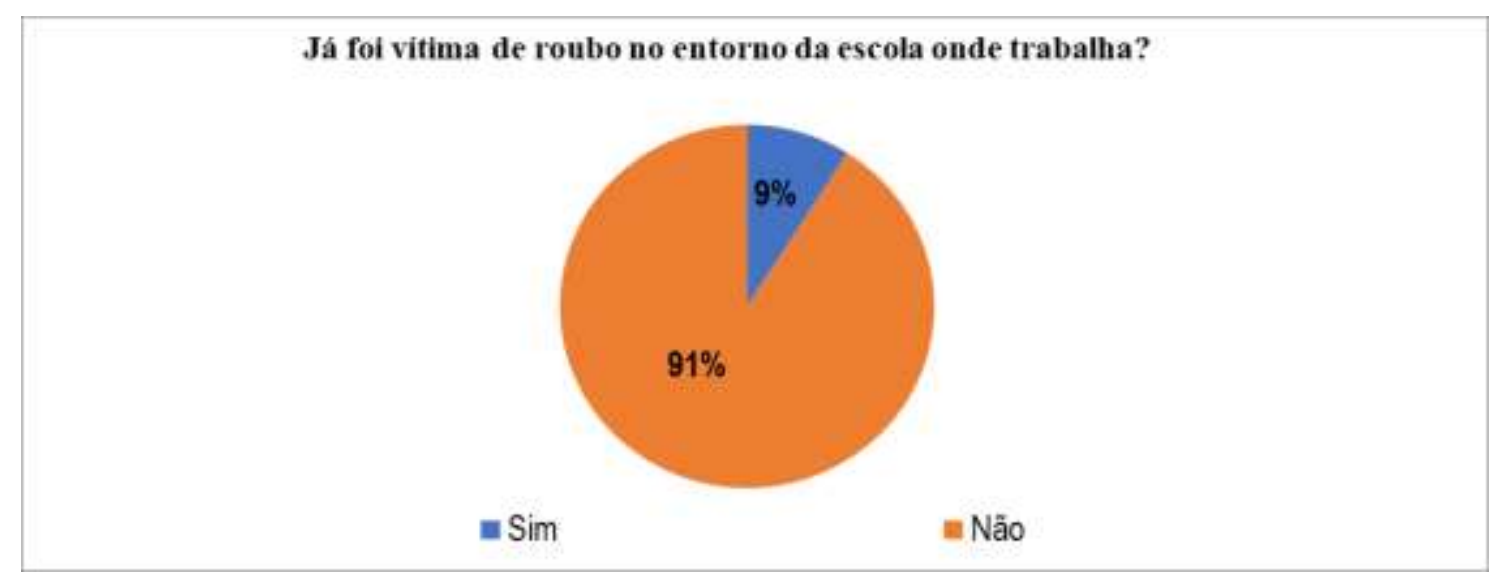

Elaboração: Os Autores (2019)

Mesmo a maioria não ter sido vítima de roubos no entorno das escolas, há registros e relatos de profissionais da educação que foram vítimas dessa prática criminal.

Estava saindo da escola, assim que virei a rua, dois caras em uma moto me pararam e levaram a minha bolsa. (Secretaria de Escola Pública Estadual na zona centro-oeste de Manaus). 
Quando questionado sobre já ter mudado de escola por conta da violência, 39\% dos que responderam ao questionário disseram que sim (Figura 16).

Figura 16. Gráfico em relação a mudar de escola por conta da violência.

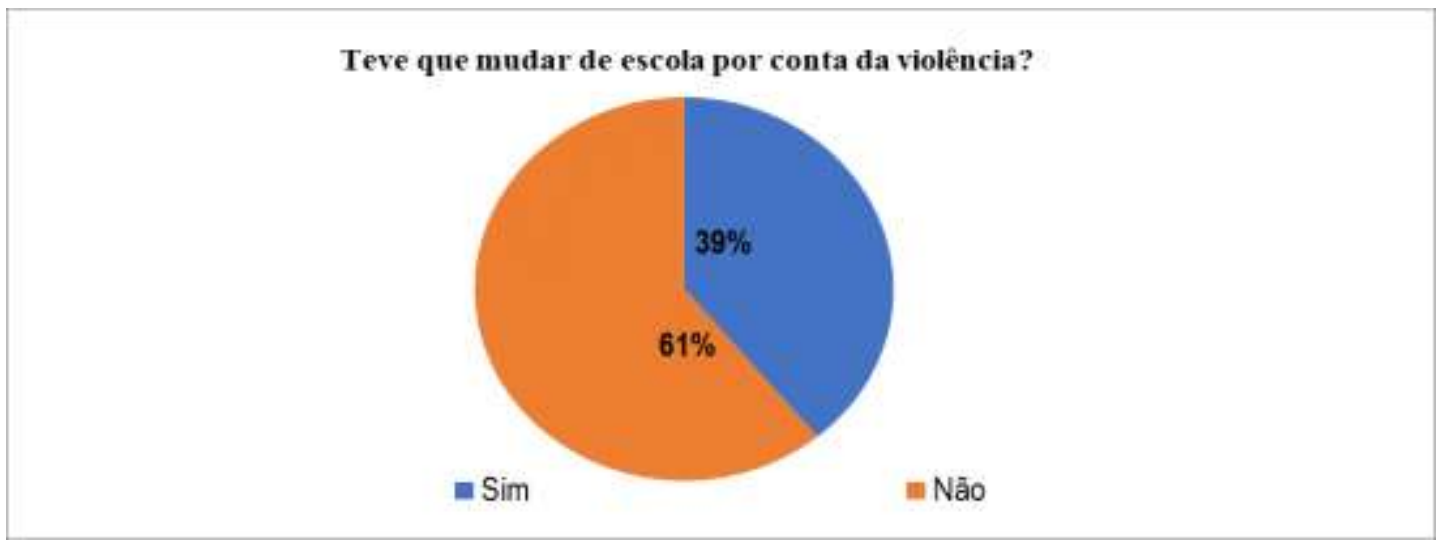

Elaboração: Os Autores (2019)

$\mathrm{Na}$ entrevista, seus relatos não ficaram somente em suas experiências pessoais, foram revelados outros casos de profissionais da educação que por conta da violência tiveram que mudar de escola.

Eu mesma! Dava aulas no colégio logo acima, fui assaltada duas vezes. Pedi transferência para cá e Graças a Deus nunca mais aconteceu (Professora de Escola Pública Estadual na zona leste de Manaus).

Graças a Deus nunca precisei, mas conheço alguns professores que já pediram transferência daqui por conta de assaltos (Professor de Escola Pública Estadual na zona sul de Manaus).

Por último, foi perguntado se em algum momento teve que se afastar, por licença médica, das atividades que exerce na escola, por conta da violência (Figura 17).

Figura 17. Gráfico em relação a ter que se afastar das atividades por conta da violência.

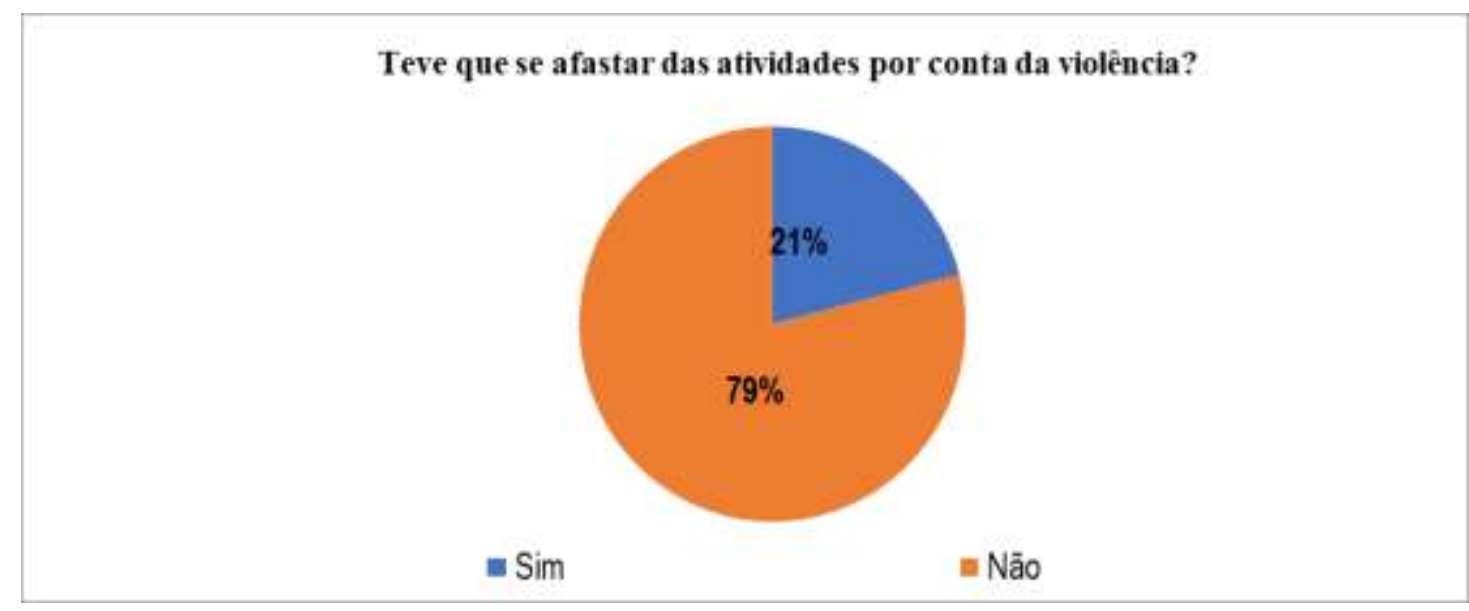

Elaboração: Os Autores (2019)

Apenas um pequeno número respondeu que sim. Contudo, conforme na pergunta anterior, diversos casos foram expostos de profissionais da educação que tiveram que se afastar das atividades que exercem para tratamento médico, por conta de assaltos.

Fiquei seis meses de licença para tratar o que o médico chamou de "Transtorno ansiedade", por conta 
de um arrastão que teve no colégio onde eu lecionava na época. Fui trancada no banheiro juntamente com outros colegas de profissão (Professora de Escola Pública Estadual na zona norte de Manaus).

Estou pleiteando uma transferência para trocar de escola. Se isso não for possível, vou pedir uma licença médica, pois fiquei muito abalado com o que passei no período noturno em uma escola que leciono. No fim da aula, fui até o carro, quando dois rapazes me abordaram e pediram pra eu dar a chave do automóvel, fiquei muito nervoso e sem pensar nas consequências corri de volta pra escola. Por sorte eles não reagiram a essa minha reação (Professor de Escola Pública Estadual na zona leste de Manaus).

Essa violência influência direta ou indiretamente a motivação profissional. Para (GURGEL e MATOS, 2012), as agressões sofridas levam os professores à desmotivação, afetando sua prática e contribuindo para uma educação de baixa qualidade.

Dentre os relatos coletados, foi possível verificar os impactos nas atividades exercidas por esses profissionais, devido a violência por eles sofrida.

Eu me assusto com facilidade, qualquer barulho mais alto eu me tremo toda e não consigo mais me concentrar (Professora de Escola Pública Estadual na zona oeste de Manaus).

Eu tinha o costume de levar notebook e data show para as aulas para torná-las mais cativante, porém depois que a escola foi assaltada, passei a levar somente meu pincel e mais nada (Professora de Escola Pública Estadual na zona norte de Manaus).

Eu trabalhava numa escola perto de casa, mas tive que pedir transferência por conta dos constantes assaltos no entorno da escola. Hoje tenho que pegar dois ônibus para trabalhar. Tornou-se muito cansativo para mim (Secretaria de Escola Pública Estadual na zona centro-oeste de Manaus).

Os traumas deixados por quem já sofreu qualquer tipo de violência seja ela física, sexual, moral ou psíquica afetam não só a vida do cidadão, mas também de toda uma coletividade. Traz angústia, ansiedade, pressão, estresse e sofrimento que podem afetar diretamente nas atividades do cotidiano, são sintomas que não respondem rápido aos tratamentos e que por isso costumam ser longos, assim como os períodos de afastamento, que chegam a durar mais de um ano. Eu fiquei oito meses afastada e agora estou me readaptando na biblioteca da escola (Professora de Escola Pública Estadual na zona norte de Manaus).

Por fim, o impacto percebido não é somente sobre a educação formal em sala de aula, mas sobre como esses profissionais conseguem lidar com suas vidas, tendo que conviver com o medo e a insegurança. Diante disso, a prática docente fica prejudicada, pois o medo e a insegurança representam uma ameaça aos pilares fundamentais na formação das crianças e dos jovens, qual seja o sistema escolar

\section{CONSIDERAÇÕES FINAIS}

O tema violência é multifacetado, quanto mais se conhece a respeito percebe-se que suas causas e consequências são complexas. Contudo, foi possível conhecer fatores importantes que nos permite discorrer algumas considerações sobre o problema e tentar dar contribuições através da visão geográfica e das observações realizadas in loco.

Foi preciso muita cautela ao tratar de um problema que tem sérias implicações na vida dos indivíduos, cujas ações vêm sendo moldadas pelo medo e pela insegurança, tendo em vista que a violência tem o potencial de influenciar no cotidiano das pessoas. Ficou evidente que entre as pessoas entrevistadas, demonstrou certo incômodo em relação a algumas perguntas realizadas. Em seus relatos, foi percebido certo nervosismo no tom de voz, como se estivessem revelando algo que não poderia ser divulgado.

Os registros de roubos as escolas públicas estaduais crescem a cada dia, e as políticas públicas de segurança são ineficientes e acabam não surtindo efeito. É necessário que a Segurança Pública tenha em mente que um bom planejamento operacional é de extrema importância para a 
diminuição dos índices de determinados crimes, onde todos os esforços devem ser direcionados na busca de bons resultados, tendo em vista que a polícia não pode estar em todos os lugares ao mesmo tempo devido ao baixo efetivo.

Existem boas iniciativas no combate aos roubos nas escolas, porém elas são fragmentadas, desconectadas e descontínuas, seja por falta de efetivo ou pela temporalidade da "gestão". Nesse caso, quando o poder público não se faz presente em um local, o crime organizado ocupa este lugar, tornando a prática de casos de violência mais rotineiros.

O mapeamento da criminalidade aparece como uma ferramenta para ajudar na visualização, planejamento, e tomada de decisão para determinadas situações que comprometem a ordem pública, pois a espacialização das ocorrências permite uma ação mais eficiente sobre as mesmas. Porém, uma dificuldade encontrada foi de se obter informações sobre os roubos as escolas públicas estaduais. Os dados existem, mas requer um trabalho desgastante para refinálos e transformá-los em informações úteis para o Sistema de Segurança no combate a violência.

O sistema de segurança utilizado nas escolas mostrou-se ineficiente para conter os roubos. Foi observado nas visitas realizadas que a localização do botão do pânico nas escolas é incorreta, pois geralmente encontra-se na sala do diretor, onde não há visibilidade externa, impossibilitando identificar uma situação de perigo. Outra observação importante que compromete a segurança nas escolas foi a falta de um padrão de abordagem dos agentes de portaria, enquanto alguns solicitam documento de identificação, outros não o fazem, facilitando $\mathrm{o}$ acesso de quem quer que seja ao interior das escolas.

A violência transforma os espaços cotidianamente, criando novos territórios e extinguindo outros. Esses espaços tornados territórios da violência envolvem relações de poder alimentadas pelo medo. O medo deriva de vários fatores, mas dentre eles, nenhum é tão significativo quanto à violência em forma da criminalidade. Sentir medo e insegurança se tornou parte da rotina dos profissionais da educação.

Por fim, o impacto percebido não é somente sobre a educação formal em sala de aula, a desmotivação profissional, mas sobre como esses profissionais conseguem lidar com suas vidas, tendo que conviver com o medo e a insegurança, impedindo que os profissionais da educação realizem seus trabalhos de maneira satisfatória. Diante disso, a prática docente fica prejudicada, pois o medo e a insegurança representam uma ameaça aos pilares fundamentais na formação das crianças e dos jovens, qual seja o sistema escolar, afetando diretamente a prática docente, gerando prejuízos para alunos, escola e para o país.

\section{REFERÊNCIAS}

AMAZONAS, Plano Estadual de Educação no Amazonas (PEEAM), Lei no 4.183 de 26 de junho de 2015. Disponível em: <http://sapl.al.am.leg.br/sapl/normajuridica/2015/> Acesso em: 07 de maio de 2019.

BRASIL. Código Penal. Decreto-Lei no 2.848, de 7 de dezembro de 1940. Vade mecum. São Paulo: Saraiva, 2008.

BRASIL. Constituição da República Federativa do Brasil. Brasília: Senado, 1988.

CÂMARA, G.; DAVIS, C.; MONTEIRO, A. M.V. Introdução à Ciência da Geoinformação. 2005. Disponível em: http://www.dpi.inpe.br/livros.html. Acesso em: julho de 2019.

DURKHEIM, Émile. As regras do método Sociológico. São Paulo: Martin Claret, 2005.

FBSP - Fórum Brasileiro de Segurança Pública. Anuário Brasileiro de Segurança Pública 2017. São Paulo: FBSP, 2017. Disponível em: <http://www.forumseguranca.org.br>. Acesso em: 21 abr.2018.

GLAESER, E. L.; SACERDOTE, B.; SCHEINKMAN, J. A. Crime and Social Interactions. Quarterly Journal of Economics, p. 507-548, 1996. 
GURGEL, C. R.; MATOS, F. A. S. A violência contra professores: saberes e práticas. Campina Grande: Realize Editora, 2012.

IBGE - Instituto Brasileiro de Geografia e Estatística - IBGE. Censo da população das capitais brasileira, 2010. Disponível em: 〈http://www.ibge.gov.bv> Acesso em: 12 de fevereiro de 2019.

MINAYO, Maria C. de S. O desafio da pesquisa social. In: Minayo, M. C. S; DESLANDES, S. F; GOMES, R. (orgs). Pesquisa Social: teoria, método e criatividade, 28 ed., Petrópolis, RJ: Vozes, 2009

OMS. Organização Mundial da Saúde. Relatório mundial de violência e saúde. Genebra: OMS, 2002.

RODRIGUES, M. Geoprocessamento: um retrato atual. Revista Fator GIS. Sagres Cartografia e Editora, Curitiba, PR, 1993, Ano1, n², pág. 20-23.

RUA, Maria das Graças (1998). As políticas públicas e a juventude dos anos 90. In: M. G. Rua, Jovens acontecendo na trilha das políticas públicas. 2v. Brasília: CNPD, pp. 731-752.

SPÓSITO, M. P. A instituição escolar e a violência. Cadernos de Pesquisa: Revista de estudos e Pesquisa em Educação, São Paulo, n. 104, 1998.

TAVARES, L. Arquitetura da (in)segurança: estudando relações entre configuração espacial, artifícios de segurança e violência urbana no bairro Manaíra, João Pessoa, Paraíba. Dissertação de Mestrado, UFRGN, Natal, RN, 192 págs. 2012.

TEIXEIRA, M. C. S.; PORTO, M. do R. S. Violência, insegurança e imaginário do medo. Cad. Cedes, Campinas, v. 19, n. 47, p. 51-66, dez. 1998.

WILSON, Ron; SMITH, Kurt. What is applied Geography for the study of crime and public safety? A Quarterly Bulletin of Applied Geography for the Study of crime \& Public Safety, Whashington, D.C., Office of Community Oriented Policing Services, v.1, Ed. 1, mar. 2008. Disponível em: <http://www,cops.udoj.gov/files/ric/Publications/GPS _Newsletter_March_08.txt>. Acesso em: 14 julho de 2019. 